\title{
STRATEGI PENGEMBANGAN WILAYAH PERBATASAN NUSA TABUKAN KABUPATEN KEPULAUAN SANGIHE BERBASIS EKOWISATA BAHARI
}

\author{
Juita Carolina Lesawengen \\ Prodi Magister Kajian Pariwisata Universitas Udayana \\ Email juita.carolia@gmail.com
}

\begin{abstract}
Nusa Tabukan in Sangihe Islands Regency is a cluster of small islands at the outer teritorry, consist of four islands that located in the northern part on Sangihe Island. The aims of this research were to identify potential tourist attractions, analyzing internal and external factors, and formulating proper marine ecotourism strategies and programs. The results indicate that potentials attractions can be developed at Nusa Tabukan. Those are the nature and socio-culture environment. Small islands, white sandy beaches, coral reefs, mangrove forest, sea grass, dugong, local wisdom as well as economic activities on community can be developed as marine tourism attractions. However, there were some obstacles related to tourism development such as human resources, tourism facilities and infrastructure and accessibility. This research formulated the grand strategy S-O to be applied which is strategy of marine ecotourism development in border cross area, while alternative strategies are also formulated. Roles of relates stakeholder is necessary needed to ensure the development is on the right track of sustainability.
\end{abstract}

Keywords: development, marine ecotourism, border cross tourism

\section{Pendahuluan}

Sebagai negara kepulauan terbesar di dunia, Indonesia memiliki kekayaan bahari berlimpah yang tersebar di seluruh wilayah. Kekayaan laut ini menjadi hak setiap anak bangsa untuk dikelola dan dimanfaatkan bagi kesejahteraan bangsa. Tentunya, dengan tidak melupakan kewajiban untuk menjaga, memelihara, dan melestarikannya. Hasil pemanfaatan potensi dan kekayaan bahari Indonesia diharapkan dapat dinikmati oleh setiap masyarakat Indonesia secara merata. Untuk itu, pembangunan semestinya dapat dilaksanakan secara merata di seluruh wilayah Indonesia sehingga hasilnya dapat menyentuh sampai seluruh wilayah, termasuk wilayah perbatasan negara. Namun pendekatan pembangunan di masa lampau yang 
fokus pada wilayah perkotaan menjadikan wilayah pulau-pulau kecil hingga wilayah perbatasan tetap tampil dalam dalam keterbatasan, meskipun memiliki ragam sumber daya di wilayah mereka.

Pembangunan ekonomi wilayah perbatasan dapat dilakukan melalui berbagai sektor termasuk sektor pariwisata. Hal ini juga telah menjadi perhatian Pemerintah Kabupaten Kepulauan Sangihe sebagai daerah otonom baru di ujung utara Indonesia yang berbatasan laut dengan Filipina. Ditetapkan sebagai wilayah perbatasan Negara melalui Undang Undang No.77 tahun 1957, Kepulauan Sangihe juga ditetapkan sebagai Daerah Perdagangan Lintas Batas berdasarkan Keputusan Presiden RI No.6 Tahun 1975. Sebagai daerah kepulauan, Kepulauan Sangihe terdiri dari 105 pulau kecil dengan panjang pantai mencapai $297 \mathrm{~km}$.

Sebagai daerah kepulauan di perbatasan Negara, sumber daya bahari mendominasi wilayah ini. Salah satu kawasan yang memiliki sumber daya bahari yang melimpah adalah Kawasan Nusa Tabukan. Nusa Tabukan merupakan gugusan pulau dengan keindahan alam pantai, pesisir, terumbu karang serta kehidupan bawah laut yang dapat dimanfaatkan sebagai daya tarik wisata. Kawasan ini dikenal dengan eksotisme pulau kecil, pasir putih, pesisir, terumbu karang serta pemandangan laut yang Indah. Nusa Tabukan juga mulai dikenal dengan ditemukannya habitat Dugong, salah satu satwa laut yang dilindungi di Indonesia. Pulau Bukide, salah satu pulau dalam kawasan ini merupakan satu dari sembilan spot penyelaman di Kepulauan Sangihe yang dikenal dengan koloni ikan. Diving Spot di Pulau Bukide meliputi coral garden dan padang lamun. Juga terdapat Pulau Poa dan Pulau Liang, dua pulau karang tidak berpenghuni dengan hamparan pasir putih, yang merupakan rumah bagi burung kumkum putih.

Nusa Tabukan juga dikenal sebagai wilayah perikanan tangkap yang menjadi penyuplai kebutuhan perikanan di pesisir utara Kepulauan Sangihe. Masyarakat nelayan tradisional yang mendiami kawasan ini merupakan bagian dari masyarakat bahari Sangihe yang sangat menghormati laut. Dalam falsafah hidup masyarakat lokal, laut dianggap sebagai pemberi kehidupan. Penghormatan masyarakat bahari di kepulauan Sangihe dapat dilihat pada perbedaan bahasa atau penyebutan, masyarakat memiliki bahasa khusus di laut dengan makna yang lebih dalam. Penghormatan masyarakat terhadap laut juga dilakukan melaui penggunaan metode tangkap tradisional untuk menjaga kelestarian laut disekitar mereka.

Kekayaan sumber daya bahari di Nusa Tabukan belum selaras dengan kondisi sosial ekonomi masyarakat setempat. Secara administratif kawasan ini masuk dalam wilayah Kecamatan Nusa Tabukan dengan lima buah kampung didalamnya. Lemahnya daya saing ekonomi masyarakat disebabkan antara lain oleh terbatasnya pilihan / alternatif mata pencaharian penduduk pulau-pulau kecil yang cenderung homogen dan sangat tergantung pada 
sumberdaya pesisir dan laut. Secara keseluruhan, kegiatan ekonomi di Nusa Tabukan masih sangat tergantung pada aktivitas ekonomi di luar pulau, terutama pada Pulau Sangihe Besar sebagai induknya (mainland). Sebagai masyarakat yang tinggal di wilayah perbatasan, aktivitas ekonmi juga dilakukan ke Filipina Selatan dengan sistem barter. Hubungan kekerabatan dan transaksi ekonomi menjadikan sebagian masyarakat bisa berbahasa tagalog.

Upaya pengembangan ekonomi dari sektor pariwisata di Nusa Tabukan belum optimal karena berbagai faktor, seperti: keterbatasan infrastruktur, kurangnya SDM pariwisata, akesibilitas, promosi, serta faktor lainnya. Perlunya dikembangkan ekowisata bahari di kawasan ini dengan harapan adanya kontribusi nilai ekonomi baik bagi penerimaan daerah dalam tataran makro, maupun yang langsung diterima oleh masyarakat. Pengembangan Nusa Tabukan perlu direncanakan dan dikelola dengan baik untuk mencegah dampak yang dapat ditimbulkan oleh kegiatan pariwisata terhadap lingkungan, serta mendorong pertumbuhan ekonomi lokal melalui konsep pemberdayaan masyarakat. Dengan demikian pengembangan pariwisata di Nusa Tabukan tetap berada pada jalur yang benar menuju pariwisata yang berkelanjutan juga tetap mengacu kepada kaidah pengembangan ekonomi di wilayah perbatsan Negara.

Berdasarkan pemaparan diatas, maka dirumuskan pedoman berdasarkan pertimbangan terhadap permasalahan berikut: (1) Apa saja komponen produk wisata dalam menunjang ekowisata bahari di Kawasan Nusa Tabukan? (2) Bagaimana kondisi lingkungan internal dan eksternal terhadap pengembangan ekowisata bahari di Kawasan Nusa Tabukan? (3) Bagaimana strategi dan program pengembangan ekowisata bahari di Kawasan Nusa Tabukan?

\section{Beberapa Konsep}

\subsection{Pengembangan Pariwisata}

Dalam era otonomi daerah, di mana daerah memiliki kewenangan dalam merencanakan dan menyelenggarakan pembangunan maka diperlukan suatu model pembangunan yang sesuai dengan kebutuhan, kapasitas serta karakteristik wilayah masing - masing, sehingga diperlukan upaya untuk menggali potensi daerah sebagai dasar dalam perumusan strategi pembangunan. Menurut Tantra (2014) dalam merencanakan dan melaksanakan pembangunan diperlukan sebuah kerangka teoritik, yaitu paradigma berpikir yang memperhatikan ruang secara realistik. Ruang tidak berarti fisik, tetapi juga lingkungan sosial budaya dalam arti luas. Pola dasar pembangunan yang memperhatikan ruang (fisik dan non fisik) secara holistik yaitu ruang sebagai kesatuan wilayah administratif, ekonomi, historis dan empiris. Dengan demikian pola pembangunan dirumuskan 
berdasarkan kondisi dan potensi lingkungan dan manusianya.

Pengembangan destinasi wisata dalam kerangka pembangunan daerah memiliki hubungan yang erat dengan pertumbuhan ekonomi dalam tataran makro, serta peningkatan kesejahteraan masyarakat dalam tataran mikro. Sehingga pengembangan pariwisata daerah haruslah juga memperhitungkan keuntungan dan manfaat bagi banyak pihak, terutama masyarakat lokal. Pengembangan pariwisata yang baik dapat mendorong terbukanya peluang kerja, pengembangan produk lokal, serta kesempatan pendidikan dan pelatihan masyarakat.

\subsection{Potensi dan Daya Tarik}

Secara harafiah potensi dapat diartikan sebagai suatu kemampuan diri yang dapat dikembangkan. Potensi adalah kemampuan yang mempunyai kemungkinan untuk dikembangkan berdasarkan kesanggupan, kekuatan dan daya. Menurut Pendit (1999) potensi wisata adalah berbagai sumber daya yang terdapat di sebuah daerah yang bisa dikembangkan sebagai atraksi wisata. Merujuk pada pendapat Pendit tersebut, maka dapat dikatakan bahwa potensi wisata merupakan sumber daya yang bisa dimanfaatkan sebagai daya tarik / atraksi wisata untuk kepentingan ekonomi daerah dan masyarakat lokal, dengan tetap memperhatikan unsur - unsur pendukung lainnya. Potensi dapat dibedakan menurut jenisnya, yaitu: (1) Potensi fisik, merupakan potensi lingkungan alam suatu daerah, dan (2) Potensi non fisik, merupakan potensi dalam bentuk sosial masyarakat, budaya, kesenian, dan lainnya.

Terdapat berbagai pandangan terkait komponen - komponen apa saja yang membentuk kesatuan produk wisata. Menurut Cooper (1995: 81), yang menyatakan bahwa setidaknya terdapat empat komponen yang harus dimiliki suatu daya tarik wisata, yaitu : (1) Atraksi (Attraction) yaitu Natural Resources (alami) dan Man Made (buatan manusia), (2) Fasilitas (Amenities), meliputi ketersediaan infrastruktur dasar dan fasilitas pariwisata, (3) Aksesibilitas (Accesibitities), terkait dengan akses dan transportasi intra dan inter destinasi, dan (4) Pelayanan Tambahan (ancillary service), terkait dengan fasilitas pelayanan lainnya yang dibutuhkan oleh wisatawan

\subsection{Wisata Bahari dan Ekowisata}

Wisata bahari merupakan jenis wisata yang memanfaatkan potensi lingkungan wilayah pesisir dan lautan secara langsung dan tidak langsung. Kegiatan langsung diantaranya adalah berperahu, berenang, snorkeling, diving dan memancing. Wisata bahari tidak dapat dilepaskan dari kegiatan wisata alam dimana kegiatan ini sering disebut juga sebagai kegiatan wisata pantai yang memanfaatkan potensi lingkungan pantai sebagai daya tarik utama. Bentuk wisata bahari dapat berbeda sesuai karakteristik pantai dan 
lingkungan sosial budaya yang ada dilingkungan pantai tersebut. Menurut Fandeli (2002: 50), daya tarik wisata bahari wisata bersumber dari bentang laut (seascope) dan bentang darat (coastal landscape). Keindahan alam, pantai berpasir, terumbu karang, kekayaan sejarah alam merupakan atraksi utama bagi wisatawan baik itu wisatawan yang mencari ketenangan dan rekreasi maupun bagi wisatawan minat khusus yang lebih mencari aktivitas yang bersifat menantang seperti fishing atau diving (inskeep, 1991). Menurut Fandeli (2002: 50), ada tiga jenis kegiatan wisata bahari, yaitu: (1) Surface activities, Merupakan aktivitas wisata yang dilakukan di permukaan air, (2) Contact activities, Merupakan aktivitas yang dilakukan wisatawan dengan melakukan kontak air, (3) Littoral activities, Merupakan kegiatan berwisata yang dilakukan di darat.

Pengembangan pariwisata bahari dapat menyebabkan terjadinya pemasalahan lingkungan, baik lingkungan alam maupun sosial masyarakat. Dampak - dampak aktivitas pariwisata tersebut kemudian memunculkan konsep wisata yang berorientasi terhadap keberlanjutan ekologi dan pemberdayaan masyarakat. Konsep ekowisata pada dasarnya adalah konsep pengembangan pariwisata yang memandang sumber daya wisata sebagai bagian dari ekosistem dimana terjadi interaksi antara sistem lingkungan, ekonomi dan sosial sehingga dalam pengembangnnya harus mempertimbangkan tercapainya ekologis, peningkatan kualitas hidup dan keberlanjutan ekonomi. Konsep wisata ini tidak hanya sekedar untuk melakukan aktivitas wisata tetapi terkait juga dengan konsep pelestarian lingkungan dan pemberdayaan masyarakat lokal. Definisi tentang ekowisata dikemukakan oleh The International Ecotourism Scociety (TIES) tahun 1990 sebagai berikut "Ekowisata adalah kegiatan wisata alam yang bertanggung jawab dengan menjaga keaslian dan kelestarian lingkungan dan meningkatkan kesejahteraan penduduk setempat”. Dari pengertian tersebut dapat dilihat bahwa dalam kegiatan ekowisata terkandung unsur - unsur kepedulian, tanggung jawab, dan komitmen terhadap pelestarian lingkungan serta kesejahteraan masyarakat. Ekowisata merupakan upaya untuk memaksimalkan sekaligus melestarikan potensi sumber daya alam dan sosial budaya dalam konteks pembangunan ekonomi berkelanjutan.

\section{Metode Penelitian}

Penelitian ini menggunakan metode penelitian kualitatif. Pendekatan penelitianinidigunakan untukmenganalisis, menguraikan, sertamemberikan penjelasan secara komprehensif dan sistematis tentang objek yang diteliti (Sugiyono, 2007). Dalam penelitian ini, peneliti merupakan instrument kunci sedangkan penentuan informan sebagai sumber data dilakukan secara purposif. Pendekatan ini digunakan untuk memperoleh profil destinasi, kebijakan, data demografis, serta harapan dan penilaian stakeholder terkait. 
- lubang batu di puncak pulau. Burung-burung ini setiap harinya bermigrasi ke Pulau Sangihe besar dan akan kembali ke Pulau Poa dan Pulau Liang pada sore harinya. Pulau Poa dan Pulau Liang dimanfaatkan untuk kegiatan fotografi dan pengamatan burung.

\section{b. Wilayah Perairan dan Lingkungan Bawah Laut}

Wilayah perairan Nusa Tabukan sejak lama telah dimanfaatkan oleh masyarakat Nusa Tabukan dan pulau-pulau kecil di sekitarnya, serta masyarakat pesisir utara Pulau Sangihe Besar untuk mencari ikan. Wilayah perairan Nusa Tabukan dikenal sebagai wilayah tangkapan yang menyuplai kebutuhan ikan di Pulau Sangihe Besar. Melimpahnya jenis dan jumlah ikan di kawasan ini mendorong pemerintah Kabupaten Kepulauan Sangihe menetapkan kawasan ini masuk dalam klaster pengembangan minapolitan. Minapolitan merupakan kawasan pengembangan ekonomi yang berbasis pada aktivitas bahari dan kegiatan perikanan. Selain untuk aktivitas sektor perikanan, wilayah perairan Nusa Tabukan merupakan jalur perhubungan laut Sangihe - Filipina, juga dimanfaatkan untuk aktivitas wisata bahari yaitu: diving, snorkeling, dan fishing. Potensi dan daya tarik eowisata bahari dapat dilihat pada Tabel.1.

Tabel 1. Potensi dan Daya Tarik Ekowisata Bahari di Kawasan Nusa Tabukan

\begin{tabular}{cll}
\hline \multirow{2}{*}{ Pulau } & \multicolumn{2}{c}{ Potensi Daya Tarik Wisata } \\
\cline { 2 - 3 } Pulau Nusa & P Pantai pasir putih & \multicolumn{1}{c}{ Laut / Bawah Laut } \\
& $\cdot$ Perkampungan nelayan & $\cdot$ Terumbu karang \\
& $\cdot$ Aktivitas masyarakat & $\cdot$ Habitat ikan \\
& $\cdot$ Perbukitan & $\cdot$ Terumbu karang \\
\hline Pulau Bukide & $\cdot$ Pantai pasir putih & $\cdot$ Habitat ikan \\
& $\cdot$ Hutan bakau & $\cdot$ Habitat Dugog \\
& $\cdot$ Perkampungan nelayan & $\cdot$ Aktivitas masyarakat \\
& $\cdot$ Aktivitas masyarakat & \\
\hline Pulau Poa & $\cdot$ Perbukitan & $\cdot$ Terumbu karang \\
& $\cdot$ Pantai pasir putih & $\cdot$ Habitat burung kumkum putih ikan \\
& $\cdot$ Perbukitan & $\cdot$ Aktivitas masyarakat \\
\hline Pulau Liang & $\cdot$ Habitat burung kumkum putih & $\cdot$ Terumbu karang \\
& & $\cdot$ Habitat ikan \\
& & $\cdot$ Aktivitas masyarakat \\
\hline
\end{tabular}

Sumber: Hasil Observasi, 2016

\section{c. Sosial Budaya}

Masyarakat Nusa Tabukan merupakan masyarakat monoetnis, yang seluruhnya berasal dari suku Sangihe, salah satu penandanya adalah bahasa yang digunakan sehari-hari yaitu bahasa sangihe. Sebagai bagian dari 
masyarakat bahari Sangihe, masyarakat Nusa Tabukan hidup berdampingan secara selaras dengan alam. Dalam falsafah hidup masyarakat lokal, laut merupakan pemberi kehidupan sehingga masyarakat memperlakukan laut secara khusus. Perlakuan khusus terhadap laut tercermin dalam aktivitas hidup masyarakat. Terdapat perbedaan bahasa atau penyebutan ketika berada di darat dan di laut. Masyarakat memiliki Sasahara, bahasa khusus di laut. Penggunaan bahasa dengan makna yang lebih sopan digunakan ketika berada di laut, sebagai bentuk penghormatan.

Selain penggunaan Sasahara, penghormatan terhadap laut dilakukan masyarakat melalui pembagian wilayah tangkap. Terdapat aturan tidak tertulis dalam masyarakat, yang mengarahkan masyarakat untuk tidak menangkap ikan karang di area terumbu karang Pulau Poa dan Pulau Liang, dimana area ini dikhususkan sebagai wilayah pemijahan ikan. Hal ini dilakukan untuk menyeimbangkan siklus kehidupan ikan dan biota laut lainnya. Sebagai satuan komunitas dalam struktur sosial masyarakat bahari, masyarakat Sangihe termasuk juga di wilayah Nusa Tabukan mengembangkan tradisi bahari berdasarkan nilai, kearifan dan pengetahuan yang dimilikinya.

Aktivitas ekonomi di kawasan ini sangat tergantung dari Pulau Sangihe Besar sebagai Mainland. Namun sebagai bagian dari daerah perdagangan lintas batas, masyarakat juga melakukan aktivitas ekonomi di Filipina. Terdapat keunikan dalam proses transaksi masyarakat di Filipina, dimana transaksi dilakukan melalui proses barter.

\subsection{Strategi Pengembangan}

Selanjutnya dirumuskan strategi dan program pengembangan ekowisata bahari berdasarkan analisis terhadap lingkungan internal dan eksternal.

\section{a. Strategi Strength-Opportunity (S-O)}

Strategi strength-opportunity merupakan strategi yang menggunakan kekuatan untuk memanfaatkan peluang, sehingga menghasilkan strategi pengembangan produk ekowisata bahari di perbatasan Negara. Kekuatan yang dimilikinya harus digunakan dengan semaksimal mungkin agar dapat memanfaatkan segala peluang yang ada dengan sebaik-baiknya. Strategi ini merupakan grand strategy yang dilakukan melalui pengembangan produk ekowisata bahari berdasarkan kekuatan yang dimiliki oleh kawasan Nusa Tabukan. Pengembangan produk berbasis pada sumber daya bahari, dengan mengedepankan aspek pelestarian lingkungan, peningkatan kesejahteraan masyarakat, serta tetap memperhatikan kaidah-kaidah pengembangan wilayah perbatasan Negara dengan tetap mengacu kepada peraturan perudang-undangan yang berlaku. Strategi dilakukan dengan melalui pengembangan daya tarik dengan nilai keunikan dan keunggulan kompettitif dibadingkan dengan destinasi sejenis lainnya (destination competitiveness). 


\section{b. Strategi Strength-Threat (S-T)}

Strategistrength-threat merupakan strategiyang menggunakan kekuatan untuk mengatasi ancaman, dimana strategi yang dihasilkan dalam penelitian ini adalah strategi peningkatan investasi / pengembangan kelembagaan dan strategi peningkatan kerjasama regional. Untuk menjadikan Nusa Tabukan sebagai kawasan ekowisata, maka strategi ini sangat diperlukan untuk mendukung pengembangan tersebut.

\section{c. Strategi Weakness-Opportunity (W-O)}

Upaya untuk meminimalkan kelemahan untuk memanfaatkan peluang merupakan strategi yang sangat penting digunakan dalam pengembangan sebuah destinasi pariwisata. Sehingga strategi yang ditemukan dalam penelitian ini adalah strategi pengembangan pasar dan promosi serta strategi pengembangan sarana pariwisata.

\section{d. Strategi Weakness-Threat (W-T)}

Strategi yang meminimalkan kelemahan dan menghindari ancaman merupakan strategi yang mendukung dalam pengembangan Nusa Tabukan sebagai kawasan ekowisata. Dalam strategi ini dirumuskan strategi pengembangan sumber daya manusia dan manajemen destinasi.

Rumusan strategi pengembangan dapat dilihat pada Tabel 2.

Tabel 2. Matrik Analisis SWOT Kawasan Ekowisata Nusa Tabukan

\begin{tabular}{|c|c|c|}
\hline FaktorInternal & $\begin{array}{l}\text { Strength (S) - Kekuatan } \\
\text { 1. Lingkungan Alam } \\
\text { 2. Lingkungan Sosial }\end{array}$ & 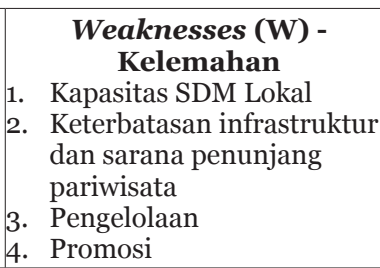 \\
\hline 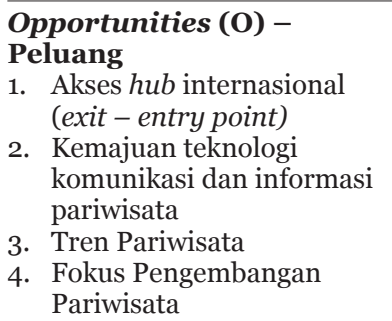 & $\begin{array}{c}\text { Strategi } S-O \\
\text { Strategi pengembangan } \\
\text { produk ekowisata bahari } \\
\text { di perbatasan Negara }\end{array}$ & $\begin{array}{c}\text { Strategi } W-O \\
\text { Strategi pengembangan } \\
\text { pasar dan promosi } \\
\text { Strategi pengembangan } \\
\text { sarana pariwisata }\end{array}$ \\
\hline $\begin{array}{l}\text { Threats (T) - Ancaman } \\
\text { 1. Isu pertahanan keamanan } \\
\text { dan stabilitas politik } \\
\text { 2. Kompetisi dengan destinasi } \\
\text { sejenis } \\
\text { 3. Konflik kewenangan } \\
\text { pengelolaan }\end{array}$ & 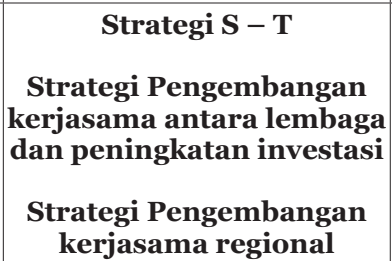 & $\begin{array}{c}\text { Strategi } W-T \\
\text { Strategi pengembangan } \\
\text { kapasitas SDM dan } \\
\text { manajemen destinasi }\end{array}$ \\
\hline
\end{tabular}

Sumber : Hasil analisis, 2016 


\section{Simpulan}

Kawasan Nusa Tabukan memiliki potensi sumber daya untuk dikembangkan sebagai kawasan Ekowisata Bahari. Keragaman sumber daya alam meliputi ekosistem pulau kecil, pantai berpasir putih, ekosistem terumbu karang, serta lingkungan bawah laut yang masih alami, ditunjang oleh tradisi dan pola hidup masyarakat bahari setempat dapat dikemas sebagai daya tarik utama di kawasan ini. Fasilitas, aksesibilitas, serta layanan penunjang pariwisata masih memiliki keterbatasan sehingga perlu upaya perbaikan. Ketersediaan sumber daya sebagai potensi wisata, juga peluang pengembangan yang ada belum mampu mendorong pengembangan kawasan ini. Terdapat berbagai faktor yang mempengaruhi kondisi ini, seperti: Keterbatasan SDM Pariwisata (kualitas dan kuantitas), minimnya infrastruktur, sistem promosi dan komunikasi pariwisata, akses dalam destinasi, fasilitas pariwisata, serta minimnya alokasi dana terhadap pengembangan pariwisata. Dalam upaya untuk mengembangkan kawasan Nusa Tabukan sebagai kawasan wisata berbasis ekowisata bahari, maka dirumuskan beberapa strategi pengembanganyang diharapkan mampu untuk menjawab kebutuhan pengembangan wisata berdasarkan analisis terhadap lingkungan internal dan eksternal. Formulasi strategi yang tepat dalam pengembangan kawasan Nusa Tabukan ini adalah strategi pengembangan produk ekowisata bahari di wilayah perbatasan. Selain itu dirumuskan juga strategi pengembangan aternatif yaitu: peningkatan kapasitas SDM dan manajemen destinasi, pengembangan pasar dan promosi, pengembangan sarana pariwisata serta peningkatan kerjasama regional dan peningkatan investasi.

\section{Ucapan Terima Kasih}

Apresiasi dan penghargaan penulis ucapkan kepada semua pihak yang telah membantu dan memberikan dukungan selama proses penelitian pun penulisan. Tanpa mengurangi rasa hormat penulis menyampaikan terimakasih kepada Prof. Made Sudiana Mahendra, Ph.D dan Dr. Ir. Syamsul Alam Paturusi, MSP selaku pembimbing atas waktu, bimbingan, serta diskusi konstruktif. Prof. Dr. I Nyoman Darma Putra, M.Litt, selaku Ketua Program Studi Magister Kajian Pariwisata, atas bantuan, koreksi dan masukan sehingga tulisan ini bisa terselesaikan. Prof. Dr. I Nyoman Sirtha, SH, MS, Dr. I Nyoman Sukma Arida, SSi, MSi dan (Alm) Dr. I Nyoman Madiun, MSc selaku penguji atas koreksi dan masukan. Terima kasih kepada Pemerintah Kabupaten Kepulauan Sangihe, masyarakat Kecamatan Nusa Tabukan serta semua pihak yang membantu penelitian ini. 


\section{Daftar Pustaka}

Badan Pusat Statistik, 2013. Sangihe Dalam Angka. Tahuna.

Badan Perencanaan Pembangunan Daerah, 2011. Profil Daerah Kabupaten Kepulauan Sangihe. Tahuna.

Cooper, C. John Fletcher, David Gilbert and Stephen Wanhill. 1995. Tourism: Principles and Practice. London: Pitman Publishing.

Fandeli, Chafid. 2002. Pengusahaan Ekowisata. Yogyakarta : Pustaka Pelajar

Hadi, Suprayoga. 2009. Program Pembangunan Kawasan Perbatasan. Jakarta: Badan Perencanaan Pembangunan Nasional.

Keputusan Presiden, 1975. Keputusan Presiden Republik Indonesia Tahun 1975 Tentang Penetapan Wilayah Ekonomis Khusus.

Pendit, Nyoman. 1999. Ilmu Pariwisata: Sebuah Pengantar Perdana. Jakarta: Pradnya Paramita.

Rangkuti, Freddy. 2013. Analisis SWOT. Jakarta: PT Gramedia Pustaka Utama. Tantra, Komang Dewa. 2014. Membaca Perubahan Bali. Denpasar : Wisnu Press Undang - Undang, 1957. Undang - Undang Nomor 77 Tahun 1957 tentang Perbatasan Negara.

\section{Profil Penulis}

Juita Carolina Lesawengen adalah alumni Program Magister Kajian Pariwisata Universitas Udayana. Sejak menyelesaikan program D-IV Kepariwisataan di Sekolah Tinggi Pariwisata Bandung tahun 2010, penulis bekerja di event organizer dan hotel di Bandung dan Bali. Tahun 2014, penulis menjadi karyasiswa pada Program Magister Kajian Pariwisata Universitas Udayana, dan hingga kini masih aktif bekerja di Industri pariwisata. Email: juita.carolina@gmail.com 